\title{
Reflective Teaching and Language Teacher Education Programmes: A Milestone in Yemen and Saudi Arabia
}

\author{
Arif Ahmed Mohammed Hassan Al-Ahdal \\ College of Science and Arts, Methnab, Qassim University, KSA; \\ Hodeidah University, Yemen \\ Salmeen Abdulrahman Abdullah Al-Awaid \\ English Language Centre, Jazan University, KSA; \\ Aden University, Yemen
}

\begin{abstract}
A language teacher faces constantly diverse class-room situations; he tries to adopt appropriate theory of learning, approach, technology, and tools and aids to create understanding in context. In doing so, he draws upon his experience and peer-experience to resolve problems and issues through the process of reflection. He takes help of research results, and does research work, sources specialist literature or undergoes need-based training - not once but repeatedly to develop competence to cope with class-room situations and remove social or psychological barriers, more particularly in the case of second or foreign language teaching. In reflective practice, the teacher summons all his faculties, experiences and appropriate theory to practise in the classroom. A language-teacher observes his students' reactions and reflects on the results after responding to such learning behaviour of the students. Following the reflection, the teacher decides to adapt or modify the theory chosen earlier. A classroom is like a laboratory where a teacher relates teaching theory to teaching practice and observes the students' responses. This paper is an attempt to give focus to the importance of reflective teaching in general with special reference to Language Teacher Education Programmes in Yemen and Kingdom of Saudi Arabia as well as check the teachers' awareness of reflective teaching. 50 teachers of English from both the countries were surveyed and interviewed for the purpose.
\end{abstract}

Index Terms - reflective teaching, language teacher education, peer teaching/interaction, ICT tools, classroom problems, teacher-training

\section{INTRODUCTION}

Reflection means, to majority of the authorities/educationists, an active, persistent and careful consideration of beliefs or supposed form of knowledge. Language teaching is more than a subject; it is complex of traditions, culture, practices and, to a great extent, communication. Language can best be taught in situations and a social setting.

Reflective teaching is the driving force to innovate for better learning solutions on the part of teachers. Modern generation is tech-savvy and open-minded, apart from being fully aware of rights as human beings and behaviorally interactive; the students do no longer form a dumb class - interaction and higher expectation from the teaching community is basic to education in a class-room setting, almost in all countries. A teacher has to be updated and communicative and given to openness- encouraging students to ask questions or raise queries to clear doubts. The following studies amply support this view:

John Dewey's research studies inspired at least four perspectives on 'Reflection':

(a) whether reflection refers to thinking about action or whether it also implies action (Gore \& Zeichner, 1995);

(b) whether reflection is relatively immediate and short-term, or an on-going process that lasts for some time;

(c) whether reflection is innately problem-centred or not. Calderhead (1989) and Schon (1987) are of the view that a problem represents lack of connection, missing life experience or meaning that must be addressed, supplied, and remedied - that reflection is analytical and seeks to form connections between known and new knowledge);

(d) whether reflection is a process of 'critical reflection' and is concerned with conscious inclusion in reflection of historical, cultural and political values and beliefs, in order to find solutions for practical problems.

Reflection as a process has been given varied descriptions. Dewey has described a logical reflective process as beginning with a perceived conflict, defined by the parameters and context of a situation. Interpretations and inferences are made concerning the interacting variables, followed by a thorough analysis of all options in order to assign meaning to the situation. The final result is that a decision is made, and a solution and a plan of action follow.

It thus, logically follows from the above-mentioned abstract thought that reflection is the essence of education. A reflective teacher considers the variables in the contexts, talks to the self (engages in intra-personal communication), considers the classroom situation, again in context, and discusses the problem or his doubts about adopting a new 
method of teaching, a new approach to the subject/topic, new teaching tools/kit and adopting some of the latest electronic devices to arouse the spirit of enquiry among the students to develop critical thinking and understanding like insatiable hunger with keenness to discuss and learn.

A reflective teacher identifies classroom problems, invites peer participation in evolving viable/feasible solutions and experiments with new ideas. While such a teacher develops by personal experience and attains proficiency through innovation and creativity, the students get inspired and actively involved in the learning process. Reflective thinking, on the part of a teacher, can be described as a recursive cycle of teacher-learning that includes using knowledge as a source of reflective observation, concrete experience, abstract conceptualization, and active experimentation. Reflective thinking and action are continuous and never ending. Relevant in this connection is a wise saying in China, reproduced below:

"If you give a man a fish, he will have a meal,

If you teach him to fish, he will have a living,

If you are thinking a year ahead, sow seeds,

If you are thinking ten years ahead, plant a tree,

If you are thinking a hundred years ahead, educate the people".

Reflective teaching and adoption of the Information Communication Technology tools (ICT tools) with the latest electronic devices will answer the futuristic educational needs of the people who are becoming increasingly interactive.

\section{REVIEW OF RELATED LITERATURE}

\section{Teacher Education}

There are seven components of education, viz., pupils/students, teachers, parents, classrooms, textbooks, curriculum/syllabus and academic institutions. All of these are complementary and supplementary to each other. All of them have to be coordinated for fruitful results. These components have to operate in perfect tandem if we are to have a sound education system. As in any area of learning, in language learning too the teachers are a significant factor. Their skills have to be honed and periodically updated in consonance with the developments taking place in the tech-savvy ambience of the advanced countries. Their education (academic) level, needs to be upgraded and knowledge updated, to help the students acquire the latest academic information and global awareness, apart from a sound understanding of the disciplines. Hence, they have to be given due attention as on them depends the success or otherwise of the teaching/ learning process. Humayun Kabir, a popular educationist in India, rightly observes, "in the absence of good teachers, even the best of systems is bound to fail, but with good teachers, the defects of the system can largely be overcome”.

In both the countries of the Arab World, Yemen and Saudi Arabia, Teacher Education has not been a systematic and planned programme; this applies both to the pre-service and in-service education/training of teachers. However, of late, there are healthy trends in evidence like theory and practice links in technical and management institutions, teaching for understanding, self-study research or what is referred to as action research. But, there are cuts in funding or inadequacy in funding, inconsistency of INSET programmes, and deficient evaluative studies on the syllabus of existing programmes and so on. Contrasts have emerged. This has generated contradictory ideas: "Teacher-Education should be expanded" or "Teacher-Education should be curtailed". In such a contradiction, the teacher-educators, teacher-trainers, student-teachers and practicing or in-service teachers are obviously in a mixed state of hope and despair. There is, therefore, a need for conducting seminars to deliberate on this subject to form an opinion for evolving a meaningful policy and programme of action.

There is a need to recruit only those teachers who have been given proper training in methods of teaching, those who have got knowledge of various learning/teaching theories and those who are trained in the use of ICT in education. Should it not be possible to find the required number all at once, then there has to be a plan of sending them in batches to the 'Teacher Training Colleges/Institutes' as early as possible. An untrained teacher can not do justice to the profession of teaching. In Yemen and also in Saudi Arabia, there is a need to give proper training to the teachereducators of languages in a systematic way. Proper syllabus has to be drawn through an expert committee. Moreover, training has to be an ongoing process, not a one shot affair because changes are occurring in the environment fast, demanding responsive action in all human activities, education; language education is no exception.

\section{Language Teacher Education}

Language teacher education is equally important if not more, in view of the international business relations and humane considerations. In the emerging scenario, there would be no country in seclusion; international cooperation, collaboration and humane consideration have established norms whereby there is accent on evolving international standards for transforming the globe into a unity with eternal peace, harmony and understanding to ensure prosperity and happy life for all irrespective of the different geological, social and cultural differences. In this situation, language teachers have a great responsibility to create supportive atmosphere for learning/teaching of English which is no longer the language of the rulers/Britain but also a shared language of the free countries on the globe. It is the international business language and sine qua non for effective international interaction. English, therefore, has to be learned as a second/ foreign language right from the Montessori-level, simultaneously with the first language. A child acquires first language of its necessity and it will acquire the second language proficiency with the same ease and interest as it does the first language at that early stage without any bias or prejudice. In childhood, a child has a blank slate of mind and it 
attempts to learn whatever is taught, of course, necessary facilities have to be ensured. This takes me to suggest that teaching of English as the second/foreign language must be introduced from the earliest stage. To enable this to happen with expected results, the method to be adopted by the English language teacher should be in a situational context; a great focus should be on listening and speaking, first, followed by reading and writing, just the same order of first language acquisition.

Given the situation, what needs to be done to strengthen this function in the general interest is a question that many of us keep asking ourselves. Our own experience as teacher-educators back home (in Yemen) suggests with conviction that the solution lies in reflection on the part of teachers, teacher-educators and/or in reflective teaching. Nonetheless, teacher-education or training (as well as re-training) remains a basic requirement, and it cannot be given a go-bye.

\section{Reflection/reflective teaching}

Reflection and reflective teaching is one of the methods to review the current approach to language teaching and to make up for any inadequacy by adopting different approach, pedagogy and methods with ICT inputs. As many studies have been conducted in other parts of the world, let us have a look at the current literature to find out what exactly the reflective teaching is.

According to Pennington (1992), Reflection or Reflective teaching is "a movement in teacher education in which student-teachers or practicing teachers analyse their own practice and its underlying basis, and then consider alternative means to achieving their ends". It is also defined as "An approach or a process in which practicing teachers and student-teachers collect data about teaching, examine their attitudes, beliefs, assumptions, and teaching practices and use the information obtained as a basis for critical reflection about teaching".

Simply put, it is the process of looking back and, after a scientific study and analysis of the classroom experience, engaging in research for remedial steps to move ahead in order to give the best possible learning to students, considering also what the students seek, reflecting on changes needed and finding suitable alternative methods or technological tools.

According to Clark and Peterson (1986), Foss and Kleinsasser (1996), a teacher's reflective way of thinking and learning has a symbiotic relationship with his/her behaviour and instruction in the classroom. Rodgers (2002) opines that teacher reflection encourages professional growth and motivation. Alsup (2006) found that only those pre-service teachers who had developed a strong sense of personal identity connected to professional identity were able to successfully transition into teaching. Freeman (1998) examined teacher thinking and learning and used the term 'teacher cognition' to describe a field of research that examined teachers' complex thought processes, including reflection, that occur when teachers plan, reorganize and revise their instruction. Fanselow (1988) gave a similar view in this regard. Greene (1986) admonished educators that the emotional investment, motivation and commitment that are intrinsically part of the reflection process, contribute to a uniquely personal experience for each teacher, and one that cannot be packaged and reproduced as a group of standard techniques. All student-teachers individually will learn to use reflection in a unique manner as they undertake their own professional development. This process leads to learning.

According to Pearsall, Skipper \& Mintzes (1997), three criteria have been identified for meaningful learning: (a) the language used in communication must be absorbed and should make sense to the participant; (b) the choice must be freely made to incorporate new concepts in a non-arbitrary, non-verbatim fashion and (c) the individual must possess a framework of concepts to anchor the new knowledge. This is uniqueness.

Hegel (1977) elaborated on the process of 'meaning-making'. He propounded that this process of 'meaning-making' is a form of self-consciousness that arises while negotiating and understanding the concept of the 'other' person and thus, requires the participation of an 'other'.

From the foregoing discussion, it follows that no two individuals can share an exact perspective, or become aware, and reflect in exactly the same manner, just because of their uniqueness and variability in cognition, which constitutes a unique identity.

The foregoing discussion of reflection used to connect knowledge concepts may involve a student-teachers' beliefs as well as knowledge. According to Grossman, Wilson \& Schulman (1989), teachers frequently "treat their teaching beliefs as knowledge". However, Grossman et al distinguished beliefs from knowledge as being based more on subjective or affective evidence and more open to dispute, as opposed to knowledge being based on fact. This leads them to the argument that construction of a teaching knowledge base involves an ongoing process of evaluation and reorganization as new knowledge causes a change in beliefs. Grossman, Wilson and Schulman (1989) do also contend that pre-service teachers' concepts about instruction, learning styles and classroom behaviour derive from their own teachers' beliefs about teaching and learning. According to Lortie (1975), when young, students establish beliefs about teaching through an 'apprentice of observations'. Bailey, Bergthold, Braustein, Fleichman, and Holbrook (1996) opine that teachers later use this store of student observations to elaborate beliefs about good and bad teaching.

There are some more points of view to add to the above discussion. These relate to the nature of reflection. John Dewey (1933), an eminent philosopher, defined reflection as an 'active, persistent, and careful consideration of any belief or supposed form of knowledge in the light of the ground that supports it and further conclusions to which it tends'. The second point of view revolves around whether reflection is relatively immediate and short-term, or an ongoing process that lasts for some time: this view is of Schon (1983). Bloom's Taxonomy (1956) suggests that for human development, there first must be connections made across the cognitive, affective, and psychomotor domains. 
There can be no absolute dictum about the process of reflection, except that it is a personalized process for each human being. Each person experiences reflection uniquely, shaped by individual ability, knowledge, and life experience, and tailored by each person to the needs at hand. A third point of view examines whether reflection is innately problemcentred or not. Calderhead (1989) and Schon (1987) say that a problem represents lack of connection, missing life experience or meaning that must be addressed, supplied and remedied. The fourth point of view is of Boud, Keogh and Walker (1985); Gore \& Zeichner (1991), and Smyth (1989). The debate spearheaded by them involves a process of 'critical reflection', and is concerned with the conscious inclusion in reflection of historical, political and cultural values or beliefs in order to find solutions for practical problems. This perspective incorporates reflection for social consciousness through connecting our awareness of others, their lives, and their needs. Van Manen (1977) views reflection as organized in three domains. He calls these as: (a) technical rationality which is dealing with efficiency of instruction in the class room; (b) practical rationality that involves the interpretation of assumptions and educational goals; (c) critical rationality or the consideration of values and ethical concerns. Each domain employs reflection for a specific educational focus: technical rationality involves consideration of class room practice and events; practical rationality implies understanding the learning experience of the student; and critical rationality considers the moral and social implications of classroom practice.

Being an ongoing process, reflection can take many forms. The chart below, adapted from Zeichner and Liston 1996: 47, cited in Bailey, K. A. Curtis and D. Nunan 2001 Pursuing Professional Development: the self as source Heinle and Heinle (Thomson Learning) 41 - 42, elaborates on these.

\begin{tabular}{|l|l|l|}
\hline Rapid reflection & $\begin{array}{l}\text { Immediate and } \\
\text { automatic }\end{array}$ & Ongoing decision-making while teaching, happens very fast, almost constantly, often privately. \\
\hline Repair & Thoughtful & Teacher makes a decision to alter behaviour in response to cues from students. \\
\hline Review & $\begin{array}{l}\text { Less formal } \\
\text { At a particular point in } \\
\text { time }\end{array}$ & $\begin{array}{l}\text { Teacher thinks about, writes about or discusses some element of teaching or students' learning; } \\
\text { often interpersonal and collegial. }\end{array}$ \\
\hline \hline Research & $\begin{array}{l}\text { More systematic } \\
\text { Over a period of time }\end{array}$ & $\begin{array}{l}\text { Thinking and observation become more sharply focused around particular issues; involves } \\
\text { collecting data over time. E. g. Action research, exploratory practice, teaching journals. }\end{array}$ \\
\hline $\begin{array}{l}\text { Re-theorizing and } \\
\text { Reformulating }\end{array}$ & $\begin{array}{l}\text { Long term } \\
\text { Informed by public } \\
\text { academic theories }\end{array}$ & $\begin{array}{l}\text { More abstract and more rigorous; teachers critically examine their practical theories, and consider } \\
\text { these in the light of academic theories. }\end{array}$ \\
\hline
\end{tabular}

To this end, teachers have to ask three main questions which form the process of reflection. These are:

1. What do I do? This question is descriptive in nature. To answer this question, a teacher should keep a record of everything he or she does in the classroom. This can be done by means of tape-recording or video-recording one's classes or taking a colleague's help in observing one's classes, also known as peer observation. It is unfortunate that some teachers are negatively disposed to peer-observation. They, mistakenly think that students will misunderstand or misinterpret the presence of a colleague in one's classes. Teachers also become conscious and that mars the free and open atmosphere, pivotal for learning.

2. What does this mean to me? This question is informative. An answer to this question is very important for the teacher to be able to justify the class activities, he/she practises by noting or mentioning the teaching principles followed.

3. How might I do things differently? This question is the be-all and end-all in the reflection process .At this stage, the teacher should think of alternatives to his/her classroom activities so that he/she can re-construct his or her own teaching process, effecting warranted changes in response to reflective thought and feedback. Thus, this stage is called the re-constructing stage in the reflection process.

In view of reflective thinking, reflective teachers have been referred to as successful practitioners/teachers by many authors. It has earned them credits and the approach has been acknowledged by experts as a positive method. Thus, for our student-teachers and practising teachers to be successful, we, as teacher-educators and teacher-trainers, have to instill in them a love of and passion for teaching and encourage them to:

1. Look forward to meeting the students in the class with a confident and cheerful disposition.

2. Enjoy teaching when in class, and not mar the beautiful process with negative body language and paralinguistic communication.

3. Reflect back with pleasure when the class is over and, think objectively to identify loopholes in the delivery process and find alternative methods to bridge the gap.

4. Be aware while in class, that the aim of 'teaching' is that "learning' must take place: this means that the success or failure of the lesson will depend taking into consideration the learners' needs, their backgrounds, their aptitudes and their roles in the classroom activities.

Naashia Mohamed suggests four ways of becoming a reflective teacher as under:

Maintain a teaching diary: This is a daily record of your professional experiences, particularly focusing on the events in the classroom. Maintaining a regular diary requires discipline as it does consume some time. But it is time 
well spent as it will help to clarify your thinking. Include in your diary not only the events that occurred during the lesson, but also your own thoughts and feelings about it as well as students' reactions and responses.

Record a lesson: Recording a lesson is a useful way of getting information about your teaching of which you might not have been aware before. You could audio or video record the lesson, making sure that the students are aware of the purposes of the recording, and that they have no objection to it. Bear in mind, however, that many students tend to be self-conscious and less willing to participate in a lesson if their responses or cues are being recorded. Lesson recordings can help you determine how much you talk; how much time you allocate to students to talk; whether you give equal attention to all the students; your movements in the classroom; your tone of voice; etc.

Obtain feedback from students: Your own students are the best people to give you a feedback on your teaching. You can do this by speaking with the class as a group or individually. You can ask them to comment on what they like and what they don't like about, what you already do in the classroom as well as about what new things they would like you to do. If the thought of getting oral feedback is a bit daunting, you could ask them to complete a simple form in the nature of a questionnaire which would give you specific information about your teaching. You may want to focus this on a particular aspect of your teaching (for example, error correction) or target the questionnaire to teaching in general, but it is preferable to get close-ended and open ended responses. This is possible and more useful if care is taken to prepare this feedback form in simple, clear, direct and understandable language. Students are generally quite open about what they think of your teaching, and provide some very good suggestions about new activities they would like you to try. There is one condition- you should be seen by them as being open to suggestions and be assured that you would not be.

Invite a colleague to observe you: presence of a superior in the class changes the overall climate; the students do not feel frank and raise fewer queries. The teacher is conscious and raises his standard to impress the boss rather them expressing in the language according to the level of students. Therefore, you may not enjoy formal observations of your teaching by a superior, but getting feedback on your teaching through a colleague may be a different experience. Again, you may ask your colleague to focus on a particular aspect of your teaching (for example, your patterns of interaction with students), or to comment on your teaching, in general. The observer can take down notes or use a standard observation form. Immediately after the lesson, make notes about what you felt were your strengths and weaknesses, and then discuss the lesson with your observer-peer (colleague).

\section{Barriers to Reflection}

The academic discussion of the process and composition of reflection frequently includes a few barriers to reflection. The inherent characteristics of teaching may discourage the development of reflection on teachers. These barriers include certain realities in teaching, such as, student teachers' prior teaching models, reluctance to reflect, lack of time, the influences of the student-teaching institutions, and the demands of teacher education programmes.

Lortie (1975); Hatton and Smith (1995); Richardson (1996) say that pre-service teachers hold beliefs acquired prior to teacher preparation that impact the ability to adopt a reflective attitude. Fanslow (1988) says that if strong prior beliefs established about teaching negatively impact reflection, novice teachers may be handicapped in planning, reorganizing and revising of their instruction. Johnson says that when unable to reflectively integrate teacher education knowledge, student teachers may reconstruct their practice without reference to their teacher education, and may turn to prior experience for a pedagogical model, reinforcing and perpetuating a previous pattern.

\section{Advantages /Characteristics of Reflective Teaching}

Reflective teachers talk unto themselves (engage in intra-personal communication and do analysis), they do not shy away from uncomfortable feedback and unpleasant question. Interaction with specialists in the field to share pedagogical perceptions is one way to enrich the teachers' repertoire. Further, teachers can share their individual pedagogical perceptions to create a richer resource bank.

Calderhead (1992) states that reflective teaching can lead to creative and innovative approaches to classroom and school situations and problems, and this could eventuate into improved learning opportunities for students. Further, reflective teachers would think critically, which involves the willingness to be questioned, taking risks in learning, trying out new strategies and ideas, seeking alternatives, taking control of learning for exploration and analysis, using higher order thinking skills; they reflect upon their own learning processes. They would discuss with others, the problems they encounter in their classroom, to aid their objective analysis of situations, which could eventuate into improved future classroom encounters. Elder \& Paul (1994); Halpern (1996), Zeichner \& Liston (1996) rightly observe, 'If a teacher never questions the goals and the values that guide his or her work, the context in which he or she teaches, or never examines his or her assumptions, then it is our belief that this individual is not engaged in reflective teaching'(p.1). This statement takes us to think of teaching as a marketable product of the mind and, therefore, it is incumbent upon the teachers to think of ways to create interest in their teaching. Stated in other words, students have to be pleasantly persuaded and motivated; learning to them should be a delightful, memorable stint of life.

Roe (1992) mentions, "language teaching is a career for life, and career development is a life-long process" (p. 1). He states that learning on the job, being informed with new ideas, reflection, and sharing ideas and experiences with colleagues increase the effectiveness of teachers and these are obtained by continuing professional development. Further, teachers' roles have changed with the changing concept of teaching. Murdoch (1994) reports his observations asserting that teachers were previously acting as knowledge transmitters; however, now they have the role of facilitators 
who create situations to help learners to use the language, and teachers who arouse students' interest and curiosity are considered successful teachers. Thus, the need for development has emerged from the changes in teachers' roles; teachers can fulfill their new roles only through CPD programmes: "...it is the development of teachers to meet the requirement of being able to engage students' interest that is single greatest challenge for those responsible for organizing in-service training courses. " Teacher development programmes offer ways to engage students' interest and the implementation of these ways provides opportunities for teachers to facilitate learning, which help teachers to adapt themselves for their new role as facilitator (p.49). Technology changes coupled with economic well being have propelled changes, and the process in never ending. Therefore, teachers have to adapt, create new approaches and innovate knowledge delivery methods on an ongoing basis.

Richards, Gallo \& Renandya (2001) claim that reflection is important in learning to teach. They assert that it is documented as a catalyst in foreign language student-teachers' professional growth. Almost similarly, Novak (2002) says that a professional-reflective teacher is an agent in meaningful learning. Bakhtin (1981) opines that a teacher's reflective experience is like an interaction, or a dialogue with a cognitive 'self'; it is an inner language, or an individual's internal voice that guides in evaluating, determining, and analyzing connections between knowledge and the events of teaching experience. Levin and Camp (2002) pointed out, "without the disposition to reflect on their performance, teachers are less likely to improve their practice or be able to see the links between theory and practice".

\section{Methodology}

This study is basically based largely on personal observation of the authors in Yemen and Kingdom of Saudi Arabia (KSA); the authors observed the same approach in teaching also in India, where they pursued Higher Studies. The observations have, however, been supported by interviews with 50 language teachers from both Yemen and KSA. Therefore, data collection was not consciously attempted. It transpired that the theory of 'reflective teaching' is not even known to the teachers; the students are also not aware of it. Current available literature has been studied for grasp over what is practised in advanced countries under 'reflective teaching' by the language teachers. Situational and contextual teaching is not attempted. For the most part, it is translation method., which is the order of the day, not even an inch has it moved towards modernity; experimentation is out of conceptual context. Some of the studies have been mentioned in this paper. This study is thus basically descriptive too, though to some extent also analytical.

\section{ANALYSIS AND RESUlts}

The studies mentioned in this paper fully support the demand of the time for teachers to be reflective and find new ways of teaching to cope with the classroom situations and improve the system, adopt new approaches and evolve student-oriented behaviour for betterment of not only students' learning but also for personal development.

Observations: The following observations are made out of the real-life study both in Yemen and KSA, supplemented by the study of various research papers/reports in regard to language teaching:

(i). None of the language teachers is ready to invite peers to observe the class during his/her teaching.

(ii). None of the language teachers discusses the teacher's note (e. g. points relating to the topic) with peer(s) for finding out whether some important point is missing from the teacher's note, before going to the class.

(iii). There is no practice, on the part of language teachers, of preparing a note on the class room situation for reflection after coming out of the class to find solutions subsequently.

(iv). Classroom situation is not discussed with peers in order to invite suggestions and evolve alternatives as possible solutions to the problem/situations confronted by the language teacher during teaching, on the part of students.

(v). Group tasks are not given as a matter of strategy; individual work does not provide scope for interaction and ease of learning.

(vi). ICT devices are either not provided or, where available, scant use is made for language teaching by the teachers concerned.

(vii). Question-answer sessions are fewer. Conversational method is rarely used.

Results: Keeping in view the above observations, the net result that is inferred by the present researchers/authors is that there is shyness on the part of teachers regarding sharing classroom situations with peers or senior/experienced teachers. There is inhibition to invite voluntarily or willingly any peer as observer in the class while teaching. There is reservation to prepare exhaustive note on points of the topic to share in the class with the help of peers. There is also no scope for experimenting different approaches to solve classroom problems and to evolve ways to make learning a pleasure and convenient to the students. There is still quite a bit of conservatism in language teachers to teach another language, and similarly there is aversion in the students to learn other language, for fear of polluting (or compromising) own culture that is preserved in own/mother/first language. Parents, teachers and students feel pride in learning own language only. For that also, reflective teaching is a far fetched dream as there is lack or absence of conducive atmosphere and lack of support from the administration/management, and there is also lack of tools/devices/ICT in learning institutions. Globalisation is not understood by the teachers and students. The emerging scenario in the global context demands that there should be a quick departure from the one-way etching method to be replaced by the modern 
system of teaching where there is place for constant research and experimentation for evolving different methods of language teaching.

\section{Discussions AND CONCLUSIONS}

It is common knowledge that a teacher knows best about the effect of his teaching each day from the responses received when some questions are asked in the class. There is no need for any other person to point out the inadequacies or to suggest better ways. But, of late, it is said that the language teacher, and other teachers also for that matter, must indulge in undertaking a review of the structuring of the lesson and identifying classroom situations to find out answer for the benefit of students although self-development is also possible through reflection on the delivery of teaching in the higher schools and colleges. In fact, reflective teaching involves changes in the way teaching is structured and delivery within the classroom is made. Experience shows that teachers who explore their own teaching quality through critical reflection or reflective teaching, develop changes in attitudes and update awareness which are beneficial in their professional growth.

Having regard to the discussions in this paper as well as the views expressed by the authorities, reproduced in the current literature, coupled with the outcome of select interviews held with teachers and students, and also the literature studied and the whole teaching/learning system observed by us, we can say that reflective teachers talk unto themselves (they engage in intra-personal communication and do analysis of classroom situations by themselves); they do not shy away from uncomfortable, inconvenient and disturbing feedback and unpleasant questions. In addition, interaction with specialists in the language education field (teaching/learning and administrative) to share pedagogical perceptions is one way to enrich the teachers' repertoire. Further, the teachers, including language teachers, can share their individual pedagogical perceptions to create a richer resource bank.

There are no two opinions that reflective teaching can lead to creative and innovative approaches to classroom and school situations and problems. Reflective way in teaching/learning could eventuate into improved learning opportunities for the language students. In this process, the reflective teachers would think critically; this involves the willingness to be questioned, taking risks in learning, trying out new strategies and ideas, seeking and evolving alternatives, taking control consciously of learning for exploration and analysis, using higher order thinking skills (acting as think tanks with the seriousness the subject deserves); they reflect upon their own learning approaches and processes. They would discuss with others (peers and seniors as well as mentors), the problems they normally encounter in their classroom, even sudden ones cropping up with surprise presence, to aid their objective analysis of situations, which could result into improved future classroom purposeful and profitable and competent encounters.

This statement takes us to think of teaching as a marketable product of the mind (service product, so to say) and, therefore, it is incumbent upon the language teachers (English language teachers per se) to think of ways to create students' interest in their teaching. Stated in other words, the students have to be pleasantly persuaded and motivated; learning to them should be a delightful and memorable experience of life, not a boring stint or burden to engineer dullness. In fact, most scholar-researchers agree that language teaching is a career for life; and career development is a life long process. It is also life long learning for the language teachers.

As far as peer interaction, without shyness of any sort, is concerned, learning on the job, being informed with new ideas, reflection, and sharing ideas and experiences with colleagues increases the effectiveness of teachers; there is surely a promise of continuing professional development. It has to be understood that the teachers' roles have undergone change in subtlety with the changing concept of teaching due mainly to the introduction of ICT and being 'student-centred': the teachers were previously acting as knowledge transmitters but now they have the role of facilitators who create situations to help learners to use the language; the teachers who arouse students' interest and curiosity through motivation (not infusing fear of any sort) are considered successful teachers. Thus, the need for development has emerged from the changes in teachers' roles; teachers can fulfill their new roles only through training/retraining, peer-level sharing and discussions and remaining student-oriented and every moment facilitators nothing different.

All in all, reflection is important in learning to teach. It is documented as a catalyst in foreign language students' and teachers' professional growth. The assertion that a professional reflective-teacher is an agent in meaningful learning by the students is accepted without reservation or contradiction (uncontroverted). We can say that a teacher's reflective experience is like an interaction, or a dialogue with a cognitive 'self'. It is an inner language, or an individual's internal voice; it guides in evaluating, determining, and analyzing connections between knowledge and the events of teaching experience (classroom situations and problems). Further, a teacher's reflective way of thinking and learning has a symbiotic relationship with his/her behaviour and instruction in the classroom. The teacher's reflection encourages his/her personal and professional growth and motivation. Only those pre-service teachers who had developed a strong sense of personal identity connected to professional identity were able to successfully transition into teaching; they experienced no difficulty as they had committed to themselves to be successful.

When we talk of learning of language (English language learning included) and, in fact, all types of learning, we see that three are certain criteria that have been identified for meaningful learning. Firstly, the language used in communication must be absorbed and should make sense to the participant. Secondly, the choice must be freely made to 
incorporate new concepts in a non-arbitrary, non-verbatim fashion. Thirdly, the individual must possess a framework of concepts to anchor the new knowledge. We can call it as uniqueness in the teacher and that is his/her asset.

Concluding, we can say that no two individuals can share an exact perspective, or become equally aware, and also be able to/capable of reflecting in exactly the same manner; the reason being that each has different degree of uniqueness and variability in cognition, which constitutes a unique identity. Further, there can be no absolute dictum about the process of reflection; it is a personalized process for each human being. Allah the Almighty has created each individual unique: so, each person experiences reflection uniquely, shaped by individual ability, knowledge, and life experience; it is tailored by each person to the needs at hand by adopting most suitable approach or method. Whenever a problem crops up, it represents lack of connection, missing life experience or meaning that must be addressed, supplied and remedied: hence there is need for continuous reflection and learning to confront situations/problems. The fact that reflection is important in learning to teach cannot be forgotten.

The learning is not, however, smooth; there are barriers in the process of reflection. The academic discussion of the process and composition of reflection frequently includes a few barriers to reflection. The inherent characteristics of teaching may discourage the development of reflection on teachers. These barriers include certain realities in teaching: these are like teachers' prior teaching models, reluctance to reflect, lack of time at disposal (as life is busy for many), the influences (working culture) of the student-teaching institutions, and the demands of teacher education programmes Syllabi). In addition, the pre-service teachers hold beliefs acquired prior to teacher preparation (pre-conditioning) that impact the ability to adopt a reflective attitude. If such strong pre-conditioning (prior beliefs established about teaching negatively) impact reflection, the 'novice' teachers may be handicapped in planning, reorganizing and revising of their instruction. Such teachers have to be given orientation/induction educative/training courses to cleanse their minds to enable them to move on the path of continuous reflection in the interest of student-community - ultimately serving society and thus smoothen the process of adopting progressive attitude.

\section{RECOMMENDATIONS AND SUGGESTIONS}

We furnish the following recommendations and suggestions regarding 'Reflective Teaching'.

- There is need for revising the recruitment and selection procedures and eligible qualifications of language/English language teachers. The regulations and criteria for admission to the teaching position and the mechanisms of the distribution (placement and posting, etc.) of teachers need to be revised in order to ensure that only qualified and attitudinally right teachers are selected; isolated rural areas may get higher priority.

- Teacher-training institutions should undertake review of the previous training concepts, practices and the content of training courses as a first step towards building a new training cycle, and monitor its impact on classroom teaching (research).

- There should be proper plan for providing regular and need-based in-service training for teachers using reflective teaching as the core (mode) of these programmes. There should be in-service training courses, at least, one programme every two years, to update teachers with the latest trends in ELT.

- There needs to be viewing other teachers' live or video recorded teaching sessions as a part of the teacher-students interaction.

- Teachers should be aware of the different roles a teacher needs to play inside the class; for instance, the role of organizer, helper, manager, guide, and confidence-booster etc. They should not stick to the role of the knowledgetransmitter alone.

- Teachers should be more involved in research and publication. Research will help them to find out the best practices that can be used in the classroom later.

- Teachers should encourage peer teaching and peer observation among themselves as a matter of practice and profit by it.

- Teachers should cultivate a practice of delivering presentations on important topics relating to teaching before their peers and respond to queries raised during such presentations.

- Teachers should discuss among themselves some peculiar classroom situations or problems to find out practical solutions.

- Teachers should make a programme (planning) for their professional growth. They should feel the need for having a development plan (career path) and set standard of their own.

- Successful and experienced academicians may be invited to talk on teaching methodology, role of IT in teaching, supervise some student activities and conduct question-answer sessions.

- Teachers should seek their students' feedback from time to time; this will help them teach the way their students learn if teachers feel that students fail to learn the way they teach.

\section{REFERENCES}

[1] Alsup, J. (2006). Teacher identity discourses: Negotiating personal and professional spaces. Mahwah, NJ: Erlbau. 
[2] Bailey, K. M., Bergthold, B., Braunstein, B., Fleischman, N. J., Holbrook, M. P., Tuman, J., et al. (1996). The language learner's autobiography: Examining the "apprenticeship of observation." In D. Freeman \& J. C. Richards (Eds.), Teacher learning in language teaching (pp. 11-29). Cambridge: Cambridge University Press

[3] Bailey, K., A. Curtis and D. Nunan. (2001). Pursuing Professional Development: The Self as Source. Boston: Thomson Learning / Heinle.

[4] Bakhtin, M. M. (1981). The dialogic imagination: Four essays. Austin, TX: University of Texas Press.

[5] Bloom B. S. (1956). Taxonomy of Educational Objectives, Handbook I: The Cognitive Domain. New York: David McKay Co Inc.

[6] Bound, D., Keogh, R. and WALKER, D. (1985). Reflection: Turning Experience into Learning, London, Kogan Page Ltd.

[7] Calderhead, J. (1989) 'Reflective Teaching and Teacher Education' Teaching and Teacher Education, Vol. 5 No.1.

[8] Calderhead, J.(1992). The Role of reflection in Learning to Teach', In Valli Linda (ed.) Reflective Teacher Education - Cases and Critiques USA: State University of New York

[9] Clark, CM., and Yinger, R.J. (1979). Teachers' thinking. In P. Peterson and H.J. Walberg (eds.), Research on Teaching. Berkeley: McCutchen.

[10] Clark, CM., and Peterson, P.L. (1986). Teachers' thought processes. In M.CWittrock (ed.), Handbook of Research on Teaching, 3rd ed. New York: MacMillan. pp. 255-96.

[11] Dewey, J. (1933). How we think. Chicago, IL: Henry Regnery.

[12] Elder, L. and Paul, R. (1994). Critical Thinking: Why we must transform our teaching. Journal of Developmental Education Fall 34-35. Retrieved September16,2013, from http://www.kcmetro.cc.mo.us/longview/ctac/ definitions.htm

[13] Fanselow, J. F. (1988). "Let's see": Contrasting conversations about teaching. TESOL Quarterly 22(1), 113-30.

[14] Foss, D. and Kleinsasser, R. (1996). Preservice elementary teachers" views of pedagogical and mathematical content knowledge. Teaching and Teacher Education, 12(4), 429-442.

[15] Freeman, J. (1998). The Education of the Very Able: Current International Research. London: The Stationery Office. (Free on www.JoanFreeman.com)

[16] Gore, J., \& Zeichner, K. 1991. Action research and reflective teaching in preservice teacher education: a case study from the United States. Teaching and Teacher Education, 7(2), 119-136.

[17] Greene, M. (1986) 'Reflection and passion in teaching', Journal of Curriculum and Supervision 2(1), 68-81.

[18] Grossman, P. L., Wilson, S. M., \& Shulman, L. S. (1989). Teachers of substance: Subject matter knowledge for teaching. In M. Reynolds (Ed.), The Knowledge Base for Beginning Teachers (pp. 23-36). New York: Pergamon.

[19] Halpern Diane F. (1996). Thought and Knowledge: An Introduction to Critical Thinking. Retrieved November 10, 2010, from http://www.kcmetro.cc.mo.us/longview/ctac/definitions.htm

[20] Hatton, N., \& Smith, D. (1995). Reflection in teacher education: Towards definition and implementation. Teaching and Teacher Education, 11, 33-49.

[21] Hegel, G. W. F. (1977). Phenomenology of Spirit, trans. A. V. Miller. Oxford: Oxford University Press

[22] Levin, B., \& Camp, J. (2002). Reflection as the foundation for e-portfolios. In D. Willis et al. (Eds.), Proceedings of Society for Information Technology \& Teacher Education International Conference 2002 (pp. 572-576). Chesapeake, VA: AACE. Retrieved from http://www.editlib.org/p/10845 on December 15, 2013.

[23] Lortie, D. (1975). Schoolteacher: A Sociological Study. Chicago: University of Chicago Press.

[24] Murdoch, G. (1994). Practising what we preach: A trainee-centered approach to in-service training. In T. Kral (Ed.), Teacher development: Making the right moves. Washington, D.C: English Language Division, United States Information Agency.

[25] Novak, J. D. (2002). Meaningful learning: The essential factor for conceptual change in limited or appropriate propositional hierarchies (liphs) leading to empowerment of learners. Science Education, 86(4), 548-571.

[26] Pennington, M. (1992). Reflecting on Teaching and Learning: a developmental focus for the second language classroom. In J. Flowerdew \& M. Brock \& S. Hsia (Eds.), Perspectives on Second Language Teacher education. Hong Kong: City Polytechnic.

[27] Pearsall, N. R., J. E. Skipper, and J. J. Mintzes. (1997). Knowledge restructuring in the life sciences: A longitudinal study of conceptual change in biology. Science Education 81:2193-215.

[28] Richards, J. C., Gallo, P. B., \& Renandya, W.A. (2001). Exploring teachers' beliefs and the processes of change. PAC Journal, 1(1), 41-58.

[29] Richardson, V. (1996). The role of attitudes and beliefs in learning to teach. In J. Sikula (Eds.), The handbook of research in teacher education (pp. 102-119). New York: Macmillan.

[30] Rodgers, C. (2002). Defining reflection: Another look at John Dewey. Teachers College Record, 104, 842-866.

[31] Roe, P. J. (1992). Career pathways for teachers- the way ahead. Tradition and Innovation -- ELT and teacher training in the 1990s. Ankara: British Council, 1-17.

[32] Schon, D.A. (1983) The Reflective Practitioner: How Professionals Think in Action, New York, Basic Books.

[33] Schon, D.A. (1987) Educating the Reflective Practitioner: Toward a New Design for Teaching and Learning in the Professions, San Francisco, Jossey-Bass.

[34] Smyth, J. (1989). Developing and sustaining critical reflection in teacher education. Journal of Education Policy, 4(4), 343-361

[35] Smith, D. C., \& Neale, D. C. (1989). The Construction of Subject Matter Knowledge in Primary Science Teaching. Teaching \& Teacher Education, 5(1), 1-20.

[36] Van Manen, M. (1977). Linking ways of knowing with ways of being practical. Curriculum Inquiry, 6(3),205-228.

[37] Zeichner, K. M. \& Liston, D. P. (1996) .Reflective Teaching- An Introduction. USA: Lawrence Erlbaun Associates, Inc. 


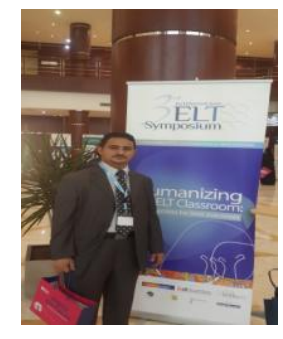

Arif Ahmed Mohammed Hassan Al-Ahdal, born in Yemen in 1982, is an Assistant Professor of English at Hodidah University, Yemen, currently working for the College of Science and Arts, Methnab, Qassim University, KSA. He earned PhD in English from Panjab University, Chandigarh, India in 2011 and obtained MA degree in TESL from the English and Foreign Languages University, Hyderabad, India in 2008. He has taught English at the tertiary level in Yemen, India and Saudi Arabia and trained high school teachers in the three said countries. He has two bi-lingual poetry collections, viz, To Yemen with Love and Joys and Sorrows, both published in 2010 by Abrar- Publishers and Distributers, Sanaa, Yemen, and has a number of other publications to his credit. His interests include Learning Strategies, ESP Course Design, Teachers' Professional Development and the use of Information and Communication Technology (ICT) in Education.

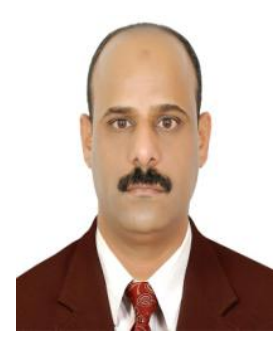

Salmeen Abdulrahman Abdullah Al-Awaid, born in Yemen in 1978, is an Assistant Professor of English (Applied Linguistics) at Aden University, Yemen, currently working for Jazan University, KSA. He was awarded MA Degree (Linguistics) by Aligarh Muslim University, India, in 2007 where he also finished his $\mathrm{PhD}$ in 2010. He has taught Linguistics to undergraduate students in Yemen, India and Saudi Arabia. He has widely published research papers in leading journals. His interests include ESP, Second Language Acquisition and Foreign Language Teaching, apart from vocabulary learning strategies and assessment. 